ORIGINAL ARTICLE

\title{
Chlorogenic acid improves the quality of boar semen processed in Percoll
}

Stenia Severo Rabelo ${ }^{1}$ (D), Carla Oliveira Resende ${ }^{1}$ (D), Thais Preisser Pontelo ${ }^{1}$ (D), Bruna Resende Chaves ${ }^{1}$ (D), Bárbara Azevedo Pereira ${ }^{1}$ (D), William Eduardo da Silva ${ }^{1}$, Juliano Vogas Peixoto ${ }^{1}$ (D), Luciano José Pereira ${ }^{2}$ (D), Márcio Gilberto Zangeronimo ${ }^{1}$ (D) *

${ }^{1}$ Departamento de Medicina Veterinária, Universidade Federal de Lavras, Lavras, MG, Brasil

${ }^{2}$ Departamento de Ciências da Saúde, Universidade Federal de Lavras, Lavras, MG, Brasil

How to cite: Rabelo SS, Resende CO, Pontelo TP, Chaves BR, Pereira BA, Silva WE, Peixoto JV, Pereira LJ, Zangeronimo MG. Chlorogenic acid improves the quality of boar semen processed in Percoll. Anim Reprod. 2020;17(1): e20190021. https://doi.org/10.21451/10.21451/1984-3143-AR2019-0021

\begin{abstract}
This study aimed to evaluate if the addition of chlorogenic acid (ChA) to semen extenders improves the quality of cooled boar semen processed in Percoll. The experimental design was randomized blocks (ejaculates) in a $2 \times 3$ factorial (with or without Percoll, and three antioxidant systems: a negative control, without supplementation, a positive control - vitamin $\mathrm{E}$, and $\mathrm{ChA}$ ), totaling six treatments and 12 repetitions. ChA and vitamin E (VE) were added at $4.5 \mathrm{mg} / \mathrm{ml}$ and $400 \mu \mathrm{g} / \mathrm{ml}$ in extender, respectively. At 0,48 and $72 \mathrm{~h}$ of storage at $15^{\circ} \mathrm{C}, 80 \mathrm{ml}$ insemination doses each containing 2.0 billion sperm cells were submitted to centrifugation in Percoll. The use of Percoll impaired $(P<0.01)$ all motility patterns but decreased $(P<0.01)$ the number of abnormal cells at 0,48 and $72 \mathrm{~h}$ of storage. Both VE and ChA improved $(P<0.05)$ the total motility after Percoll processing, but only in semen stored for $48 \mathrm{~h}$. The same effect was not observed $(P>0.05)$ in semen stored for $72 \mathrm{~h}$. ChA improved $(P<0.05)$ the total motility of the semen stored for $72 \mathrm{~h}$, but this effect was not observed $(P>0.05)$ when the semen was processed in Percoll. The antioxidants had no effect $(P>0.05)$ on the viability and integrity of the acrosome, but ChA reduced $(P<0.05)$ the number of abnormal cells at 0 , while VE increased the number of abnormal cells in semen stored for $72 \mathrm{~h}$, independent of the use of Percoll. There was no effect $(P>0.05)$ of antioxidants or Percoll on the concentration of malondialdehyde in seminal plasma. The use of Percoll had no effect $(P>0.05)$ on the cholesterol efflux, but ChA increased $(P<0.05)$ this parameter at 0 h and reduced $(P<0.05)$ in the semen stored for $72 \mathrm{~h}$ not processed with Percoll. In conclusion, the addition of ChA to semen extenders improved the quality of boar semen processed or not in Percoll.
\end{abstract}

Keywords: antioxidants, reproduction, sperm selection.

\section{Introduction}

The need for higher quality boar semen destined for artificial insemination (Al) or in vitro fertilization (IVF) has led to the emergence of different methodologies of semen processing. One of these methods, the sperm selection technique using Percoll, has been widespread (Cesari et al., 2006; Zhou et al., 2010). This technique selects sperm subpopulations with increased physical integrity by their cell density. This procedure is suitable for obtaining cells with better core structure (Le Lannou and Blanchard, 1988) and for obtaining a smaller percentage of abnormal cells (Henkel and Schill, 2003).

However, negative effects on sperm motility have been reported (Guimarães et al., 2014), probably due to the formation of reactive oxygen species (ROS) during the centrifugation process (Iwasaki and Gagnon, 1992) or by the toxicity of Percoll (De Vos et al., 1997) which

*Corresponding author: zangeronimo@ufla.br

Received: February 27, 2019. Accepted: October 24, 2019.

Funding Source: CAPES (PNPD Institutional), number process 2457/2011 and Pesquisador Visitante Especial - PVE, process number 88881.030399/2013-01),

FAPEMIG (PPM-00359-14) and CNPq (PQ 305478/2015-0).

Conflict of interest: The authors have no conflict of interest to declare.

(c) (i) Copyright (c) The Author(s). This is an Open Access article distributed under the terms of the Creative Commons Attribution License, which permits unrestricted use, distribution, and reproduction in any medium, provided the original work is properly cited. 
contains polyvinylpyrrolidone in its composition (Kato and Nagao, 2009). Besides participating in the sperm capacitation process, the presence of ROS could increase cellular abnormalities and acrosome changes, thereby limiting the quality of semen (Breininger et al., 2005). In this case, the addition of antioxidants in the extender could ease the sperm damage caused by ROS, improving the ability to maintain the quality and fertility of cooled semen for long time (Mendez et al., 2013; Pereira et al., 2014).

Vitamin E (Mendez et al., 2013) and chlorogenic acid (Basile et al., 2005; Pereira et al., 2014) are antioxidant substances that improve sperm quality when used during semen processing. Vitamin E (tocopherol) is a non-enzymatic antioxidant (Maneesh and Jayalekshmi, 2006) and is fat-soluble, which can protect the sperm from oxidative damage to DNA and the plasma membrane (Breininger et al., 2011). Mendez et al. (2013) reported that the addition of $400 \mu \mathrm{g} / \mathrm{ml}$ of vitamin $\mathrm{E}$ during the processing of boar insemination doses reduced the lipid peroxidation of sperm stored at $15^{\circ} \mathrm{C}$ for $72 \mathrm{~h}$. Furthermore, chlorogenic acid is a water soluble phenolic compound, that is widely distributed in nature and found primarily in vegetables (Basile et al., 2005). The presence of $4.5 \mathrm{mg} / \mathrm{mL}$ of chlorogenic acid in boar semen appears to improve the quality of insemination doses, especially when stored for periods longer than $24 \mathrm{~h}$ (Pereira et al., 2014).

Thus, this study aimed to determine whether the addition of vitamin $\mathrm{E}$ or chlorogenic acid extenders improves the quality of cooled boar semen processed with Percoll.

\section{Methods}

\section{Semen collection and processing of insemination doses}

The experiment was conducted at the Swine Reproduction Laboratory of the Veterinary Medicine Department of the Federal University of Lavras (UFLA) in Lavras, Minas Gerais, Brazil. All procedures were approved by the Ethics Committee on Animal Use of UFLA (protocol number 034/16).

A total of 16 ejaculates from four boars (four ejaculates each) of Duroc, Large White and Pietrain breeds, aged between 24 to 48 months and belonging to the Swine Experimental Center of UFLA, were used for this experiment. The animals were housed in individual grid stalls ( $2.75 \mathrm{~m}$ length $\times 2.10 \mathrm{~m}$ width and $1.30 \mathrm{~m}$ height) and fed daily with $3 \mathrm{~kg}$ of boar feed, divided into two feeding periods, at 8:00 am and at 2:00 pm. The water supply was provided ad libitum. Every animal was considered clinically healthy and of proven fertility. Weekly, three ejaculates were collected from each animal, always on alternate days.

Semen was collected by the gloved hand method in a specific room with the use of an immobile dummy. Before collection, the prepuce was cleaned and sanitized with paper towels. The semen was collected, and the gel fraction was discarded using a specific filter (Minitub do Brasil LTDA ${ }^{\circledR}$, Porto Alegre, Brazil).

The experiment was conducted in a block design (ejaculates) in a $2 \times 3$ factorial scheme (with or without Percoll and three antioxidant systems: a negative control, without the addition of antioxidants; a positive control, with addition of VE; and chlorogenic acid), totaling six treatments and 12 repetitions of each ejaculate.

Before semen collection, three BTS (Beltsville Thawing Solution ${ }^{\circledR}$ - Minitub of Brazil LTDA) extenders were prepared: without the addition of antioxidants, with $4.5 \mathrm{mg} / \mathrm{ml}$ of chlorogenic acid (chlorogenic acid crystalline, C3878 - Sigma-Aldrich ${ }^{\circledR}$ ) (Pereira et al., 2014) or with $400 \mu \mathrm{g} / \mathrm{ml}$ of vitamin E (DL-a-tocoferol acetate, T3251 - Sigma-Aldrich ${ }^{\circledR}$ ) (Mendez et al., 2013), all maintained at $35^{\circ} \mathrm{C}$. Immediately after semen collection, sperm concentration was determined in a Neubauer chamber after diluting a sample of ejaculate in formaldehyde citrate solution at a ratio of 10:1000 (semen: formaldehyde citrate solution). Sperm count was estimated from the cell count in a 10-field Neubauer chamber under optical microscopy.

From each ejaculate, three inseminating doses of $40 \mathrm{~mL}$ containing two billion spermatozoa each were processed using one of the three extenders previously prepared. The insemination 
doses were then stored at room temperature and protected from light for $40 \mathrm{~min}$, after which they were stored in a refrigerator at $15^{\circ} \mathrm{C}$.

At 0,48 and $72 \mathrm{~h}$ of storage, $2.0 \mathrm{ml}$ samples of semen were centrifuged (Heraeus Megafuge 16R Centrifuge, LED Thermo Electron $\mathrm{GmbH}$, Osterode, Germany) at 1,000 $\times \mathrm{g}$ for 15 minutes at $37{ }^{\circ} \mathrm{C}$ in $24 \times 150 \mathrm{~mm}$ test tubes containing $2.0 \mathrm{ml}$ of Percoll (Percolltm, GE Healthcare Uppsala, Sweden) previously prepared in a $45 / 90$ density gradient in $0.9 \%$ saline solution (Zhou et al., 2010). After this procedure, the samples were washed with $500 \mu \mathrm{L}$ of BTS by centrifugation of $1,000 \times \mathrm{g}$ for $10 \mathrm{~min}$ at $37^{\circ} \mathrm{C}$. The sperm sediment at the bottom of the test tube was collected, diluted in $3.0 \mathrm{~mL}$ of BTS at $37{ }^{\circ} \mathrm{C}$ and maintained th themperature for 15 min for microscopic and biochemical evaluations.

\section{Microscopic evaluations}

All kinetic parameters were analyzed in the CASA system (Sperm Class Analyzer SCA 5.0, Microptic, Barcelona, Spain). For the test, $3.0 \mu \mathrm{L}$ of semen was put in a specific glass plate (20 microns Leja ${ }^{\circledR}$ - Microptic, Barcelona, Spain) preheated to $37^{\circ} \mathrm{C}$. The images were captured at $100 \times$ magnification.

To assess the amount of abnormal cells, $200 \mu \mathrm{L}$ semen samples were diluted into $700 \mu \mathrm{L}$ of sodium-citrate aldehyde formalin solution at 3\% (Pursel et al., 1972). Subsequently, $10 \mu \mathrm{L}$ of this mixture was placed between a microscope slide and coverslip and evaluated under phase contrast microscopy (Olympus CX31, Olympus - Tokyo, Japan) at $1000 \times$ magnification. Changes in the acrosome, head, middle piece and tail were recorded in a total of 200 cells. The values were expressed in percentages considering the total number of alterations detected in relation to the total number of cells analyzed.

Sperm viability was measured after mixing a drop of semen with a drop of eosin-nigrosin stain (Blom, 1950). After smearing on a microscope slide, a total of 200 cells was evaluated under a light microscope (Olympus CX31, Olympus - Tokyo, Japan) at $400 \times$ magnification. Unstained cells were considered to have intact membranes and stained cells were considered dead. Values were expressed as the percentage of cells with intact membranes compared to the total number of cells counted.

To evaluate acrosome integrity, $10 \mu \mathrm{l}$ of semen was added to $10 \mu \mathrm{l}$ of dye POPE - Fast Green / Rose Bengal (Pope et al., 1991) and incubated for $60 \mathrm{~s}$ at $37^{\circ} \mathrm{C}$. After this period, 200 cells were then evaluated under phase contrast microscopy (Olympus CX31, Olympus - Tokyo, Japan) at $1000 \times$ magnification. Cells with the acrosome region stained blue were considered to have intact acrosomes, and cells with the acrosome region unstained or only slightly stained were considered unhealthy.

\section{Biochemical evaluations}

Biochemical analyses were performed on $1.0 \mathrm{ml}$ samples of semen centrifuged at 3,000 $\times \mathrm{g}$ for ten minutes (Ahluwalia and Holman, 1969). The supernatant was transferred to polypropylene tubes and frozen at $-80^{\circ} \mathrm{C}$ until the day of analysis.

To evaluate the concentration of malondialdehyde (MDA) in seminal plasma, the TBARS QuantiChromTM Kit Assay (DTBA- 100- Bioassay Systems - Hayward, USA) was used following the manufacturer's instructions (Brezezińska-Slebodzińska et al., 1995). For measurement of total cholesterol in the seminal plasma, the commercial kit Cholesterol Oxidase (Labtest Diagnosis S.A., Lagoa Santa, Brazil) was used following the manufacturer's instructions (Melo et al., 2009).

\section{Statistical analysis}

The data were submitted to a normality test and homogeneity of variances by the Levene test, and then the analysis of variance (ANOVA). For the variables that did not meet the assumptions of ANOVA was used for the square root transformation of the data. The effect of 
males was considered in the model and all interactions were studied when $\mathrm{P}<0.05$ by ANOVA. Means were compared by Tukey's test at $5 \%$. All statistical analyses were performed using the statistical package Action version 3.0.2.

\section{Results}

There was a significant interaction $(P<0.05)$ between the use of antioxidants and the Percoll technique regarding total motility in boar semen stored for 48 or $72 \mathrm{~h}$ (Table 1). Both vitamin $E$ and chlorogenic acid improved $(P<0.05)$ the total motility when semen stored for $48 \mathrm{~h}$ was processed in Percoll. However, the same effect was not observed $(P>0.05)$ when the semen was stored for $72 \mathrm{~h}$ (Figure 1). With $72 \mathrm{~h}$ of storage, chlorogenic acid improved $(\mathrm{P}<0.05)$ the total motility of semen not processed in Percoll; however, the same effect was not observed $(P>0.05)$ when Percoll was used.

Table 1. Motility patterns of cooled boar semen after the addition of chlorogenic acid (CA) ( $4.5 \mathrm{mg} / \mathrm{ml})$ or vitamin $\mathrm{E}(\mathrm{VE})(400 \mu \mathrm{g} / \mathrm{ml})$ to the extender, with or without the use of the Percoll sperm selection technique $(n=12)$.

\begin{tabular}{|c|c|c|c|c|c|c|c|c|c|}
\hline \multirow{2}{*}{ Storage time } & \multicolumn{2}{|c|}{ Percoll (Pe) } & \multicolumn{3}{|c|}{ Antioxidant (Ao) } & \multirow{2}{*}{ CV (\%) } & \multicolumn{3}{|c|}{ Pvalue } \\
\hline & With & Without & Without & CA & VE & & $\mathrm{Pe}$ & Ao & $\mathrm{Pe}{ }^{\star A O}$ \\
\hline \multicolumn{10}{|c|}{ Total motility (\%) } \\
\hline 0 hours & 84.1 & 88.1 & 83.8 & 88.0 & 86.8 & 8.96 & 0.04 & 0.16 & 0.98 \\
\hline 48 hours & 46.0 & 74.3 & $53.6^{\mathrm{b}}$ & $65.4^{a}$ & $64.1^{a}$ & 10.72 & $<0.01$ & $<0.01$ & 0.03 \\
\hline 72 hours & 26.3 & 66.8 & $44.8^{b}$ & $54.2^{a}$ & $43.9^{b}$ & 10.00 & $<0.01$ & $<0.01$ & 0.06 \\
\hline \multicolumn{10}{|c|}{ Progressive motility (\%) } \\
\hline 0 hours & 30.8 & 46.4 & 41.9 & 46.7 & 43.9 & 14.74 & $<0.01$ & 0.14 & 0.21 \\
\hline 48 hours & 13.2 & 27.6 & 22.4 & 24.6 & 19.9 & 16.95 & $<0.01$ & 0.28 & 0.93 \\
\hline 72 hours & 1.82 & 12.6 & 8.69 & 8.79 & 9.82 & 11.04 & $<0.01$ & 0.30 & 0.12 \\
\hline \multicolumn{10}{|c|}{ VAP - Velocity average path $(\mu \mathrm{m} / \mathrm{s})$} \\
\hline 0 hours & 39.5 & 47.5 & 42.9 & 44.6 & 43.6 & 9.64 & $<0.01$ & 0.77 & 0.87 \\
\hline 48 hours & 21.9 & 31.9 & 28.0 & 25.0 & 28.8 & 15.97 & $<0.01$ & 0.12 & 0.14 \\
\hline 72 hours & 12.5 & 26.0 & 19.9 & 17.8 & 21.1 & 12.49 & $<0.01$ & 0.14 & 0.16 \\
\hline \multicolumn{10}{|c|}{ ALH - amplitude of lateral head displacement $(\mu \mathrm{m})$} \\
\hline 0 hours & 2.01 & 2.28 & 2.22 & 2.10 & 2.13 & 10.09 & $<0.01$ & 0.69 & 0.64 \\
\hline 48 hours & 1.51 & 1.65 & 1.61 & 1.52 & 1.63 & 7.48 & 0.01 & 0.30 & 0.36 \\
\hline 72 hours & 1.28 & 1.61 & 1.55 & 1.38 & 1.43 & 12.12 & $<0.01$ & 0.12 & 0.13 \\
\hline \multicolumn{10}{|c|}{ LIN - Linearity (\%) } \\
\hline 0 hours & 0.524 & 0.549 & 0.527 & 0.569 & 0.517 & 11.32 & 0.10 & 0.12 & 0.19 \\
\hline 48 hours & 0.362 & 0.539 & 0.436 & 0.485 & 0.444 & 14.15 & $<0.01$ & 0.49 & 0.18 \\
\hline 72 hours & 0.353 & 0.511 & 0.401 & 0.455 & 0.451 & 11.28 & $<0.01$ & 0.25 & 0.21 \\
\hline \multicolumn{10}{|c|}{ WOB - Wobble (\%) } \\
\hline 0 hours & 0.711 & 0.750 & 0.730 & 0.745 & 0.720 & 5.85 & $<0.01$ & 0.17 & 0.23 \\
\hline 48 hours & 0.553 & 0.714 & 0.626 & 0.650 & 0.638 & 8.95 & $<0.01$ & 0.86 & 0.11 \\
\hline 72 hours & 0.511 & 0.693 & 0.578 & 0.610 & 0.633 & 7.15 & $<0.01$ & 0.12 & 0.21 \\
\hline
\end{tabular}

Means followed by different letters in the line differ by Tukey's test $(P<0.05)$. CV: Coefficient of variance. 

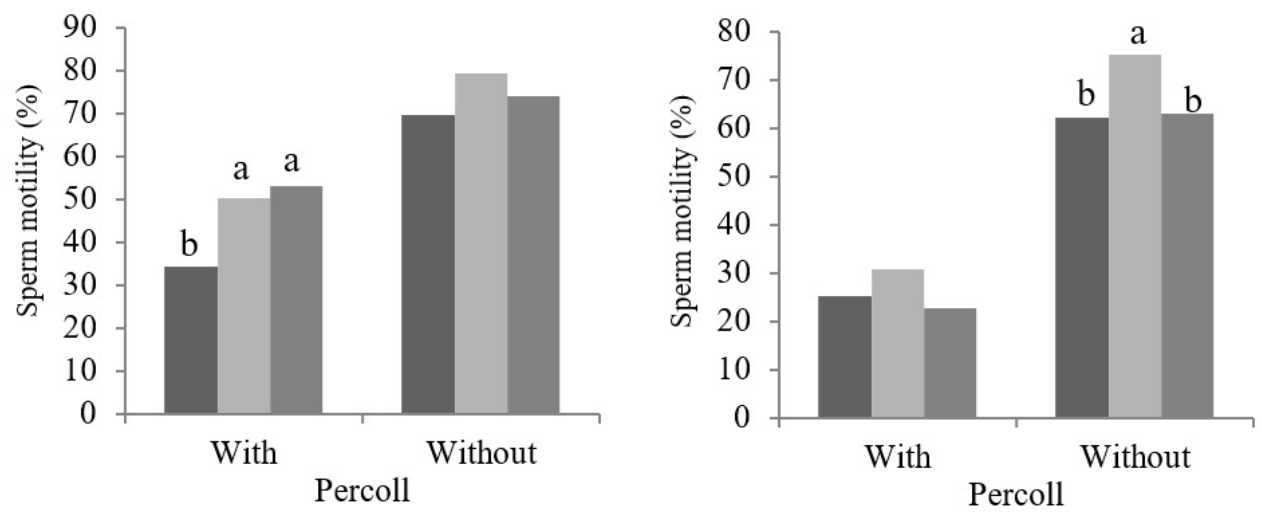

Control $\square \mathrm{CA} \square \mathrm{VE}$

Figure 1. Total motility in the cooled boar semen after the addition of chlorogenic acid (CA) $4.5 \mathrm{mg} / \mathrm{ml})$ or vitamin $\mathrm{E}(\mathrm{VE})(400 \mu \mathrm{g} / \mathrm{ml})$ to the extender, with or without the use of the Percoll sperm selection technique $(n=12)$. Means followed by different letters differ by Tukey's test $(P<0.05)$.

No interaction $(P>0.05)$ between antioxidants and the Percoll technique was detected for other motility patterns, sperm viability, acrosomal integrity, percentage of abnormal cells (Table 2) or MDA concentration in the seminal plasma (Table 3). The Percoll technique was efficient $(P<0.01)$ in reducing the percentage of abnormal cells, but damaged $(P<0.01)$ all motility patterns. The viability was improved $(P<0.01)$ by the Percoll technique only in the semen stored for $48 \mathrm{~h}$. There was no effect $(P>0.05)$ of the Percoll technique on the MDA concentration in the seminal plasma.

Table 2. Sperm viability, acrosome integrity and percentage of abnormal cells in the cooled boar semen after the addition of chlorogenic acid (CA) $(4.5 \mathrm{mg} / \mathrm{ml})$ or vitamin $\mathrm{E}(\mathrm{VE})(400 \mu \mathrm{g} / \mathrm{ml})$ to the extender, with or without the use of the Percoll sperm selection technique $(n=12)$.

\begin{tabular}{|c|c|c|c|c|c|c|c|c|c|}
\hline \multirow{2}{*}{ Storage time } & \multicolumn{2}{|c|}{ Percoll (Pe) } & \multicolumn{3}{|c|}{ Antioxidant (Ao) } & \multirow{2}{*}{ CV (\%) } & \multicolumn{3}{|c|}{ P value } \\
\hline & With & Without & Without & CA & VE & & $\mathrm{Pe}$ & Ao & $\mathrm{Pe}^{\star} \mathrm{Ao}$ \\
\hline \multicolumn{10}{|c|}{ Sperm viability (\%) } \\
\hline 0 hours & 87.4 & 86.4 & 86.8 & 87.1 & 86.8 & 4.73 & 0.28 & 0.95 & 0.17 \\
\hline 48 hours & 86.4 & 82.1 & 83.4 & 84.0 & 85.4 & 5.51 & $<0.01$ & 0.31 & 0.26 \\
\hline 72 hours & 83.8 & 81.9 & 83.9 & 81.3 & 83.3 & 5.01 & 0.09 & 0.14 & 0.50 \\
\hline \multicolumn{10}{|c|}{ Acrosome integrity (\%) } \\
\hline 0 hours & 94.9 & 96.6 & 95.7 & 95.7 & 95.9 & 1.60 & $<0.01$ & 0.86 & 0.31 \\
\hline 48 hours & 91.0 & 90.8 & 90.3 & 91.7 & 90.7 & 3.93 & 0.80 & 0.37 & 0.29 \\
\hline 72 hours & 89.7 & 89.9 & 89.3 & 89.9 & 90.3 & 3.40 & 0.76 & 0.62 & 0.58 \\
\hline \multicolumn{10}{|c|}{ Abnormal cells (\%) } \\
\hline 0 hours & 4.12 & 6.44 & $5.07^{\mathrm{ab}}$ & $3.54^{b}$ & $7.24^{a}$ & 9.07 & $<0.01$ & $<0.01$ & 0.12 \\
\hline 48 hours & 5.81 & 10.00 & 8.41 & 7.81 & 7.50 & 8.74 & $<0.01$ & 0.79 & 0.42 \\
\hline 72 hours & 7.25 & 10.12 & $7.43^{b}$ & $6.11^{\mathrm{b}}$ & $12.51^{a}$ & 7.81 & $<0.01$ & $<0.01$ & 0.15 \\
\hline
\end{tabular}

Means followed by different letters in the line differ by Tukey's test $(P<0.05)$. CV: Coefficient of variance.

Table 3. Malondialdehyde level $(\mu \mathrm{M})$ in cooled boar semen after the addition of chlorogenic acid (CA) $(4.5 \mathrm{mg} / \mathrm{ml})$ or vitamin $\mathrm{E}(\mathrm{VE})(400 \mu \mathrm{g} / \mathrm{ml})$ to the extender, with or without the use of the Percoll sperm selection technique $(n=12)$.

\begin{tabular}{|c|c|c|c|c|c|c|c|c|c|}
\hline \multirow{2}{*}{ Storage time } & \multicolumn{2}{|c|}{ Percoll (Pe) } & \multicolumn{3}{|c|}{ Antioxidant (Ao) } & \multirow{2}{*}{ CV (\%) } & \multicolumn{3}{|c|}{ P value } \\
\hline & With & Without & Without & CA & VE & & $\mathrm{Pe}$ & Ao & $\mathrm{Pe}^{\star} \mathrm{Ao}$ \\
\hline 0 hours & 0.910 & 0.864 & 0.884 & 0.868 & 0.907 & 15.57 & 0.57 & 0.98 & 0.24 \\
\hline 48 hours & 0.716 & 0.858 & 0.767 & 0.813 & 0.775 & 22.42 & 0.10 & 0.84 & 0.88 \\
\hline 72 hours & 0.708 & 0.809 & 0.701 & 0.866 & 0.726 & 15.46 & 0.13 & 0.13 & 0.58 \\
\hline
\end{tabular}

No difference by the F-test $(P>0.05)$. 
The antioxidants had no effect $(P>0.05)$ on sperm viability or acrosome integrity. Independent of the use of the Percoll technique, chlorogenic acid reduced $(P<0.05)$ the percentage of abnormal cells in fresh semen $(0 \mathrm{~h})$, while vitamin $E$ increased $(P<0.05)$ this parameter in the semen stored for $72 \mathrm{~h}$. There was no effect $(P<0.05)$ of antioxidants on the MDA concentration in seminal plasma.

A significant interaction $(P<0.05)$ between antioxidants and the Percoll technique was observed for the cholesterol concentration in seminal plasma. In fresh semen, chlorogenic acid increased $(P<0.05)$ the cholesterol levels in seminal plasma only when the Percoll technique was used. For semen already stored for $72 \mathrm{~h}$, when compared to the control (without antioxidant addition), chlorogenic acid reduced $(P<0.05)$ the concentration of cholesterol only in semen not processed in Percoll. The Percoll technique had no effect $(P>0.05)$ on the cholesterol efflux of boar semen.

\section{Discussion}

While the Percoll technique was efficient in selecting sperm cells with fewer abnormalities, it reduced all sperm motility patterns regardless of the addition of antioxidants to the extender. This result indicates that both chlorogenic acid and vitamin E were not effective in mitigating the negative effects caused by Percoll.

The Percoll technique is recommended for IVF (Matás et al., 2011). In these cases, the physical cellular integrity is more important than the locomotor ability of the spermatozoa. However, use of the Percoll technique to produce insemination doses for in vivo fertilization is not yet feasible.

Several studies have shown that the use of substances with antioxidant properties in the extender improves the quality of thawed boar semen (Ma et al., 2015; Shen et al., 2016), whose manipulation is intense. However, there has not been enough information to demonstrate these findings in semen processed in Percoll. The benefits expected from the use of antioxidants added to the extender could extend to the use of Percoll to produce semen for Al programs.

According to Iwasaki and Gagnon (1992), the manipulation of semen can result in the formation of ROS. The same also occurs with cooled boar semen (Martín-Hidalgo et al., 2013). It is known that ROS can damage the sperm membrane and, thus, reduce sperm motility and increase the number of damaged cells (De Lamirande and Gagnon, 1992). ROS also induce irreversible changes in the proteins and nucleic acids of spermatozoa, stimulating apoptosis and cell death (Lewis and Aitken, 2005).

However, an increased MDA concentration in seminal plasma due to the processing of semen in Percoll could not be verified in the present study. Thus, it is believed that the adverse effects of this technique on semen quality are more related to the toxicity of polyvinylpyrrolidone present in Percoll (Barak et al., 2001), although there is evidence that MDA can react with proteins and amino acids present in the media (Chio and Tappel, 1969). In this case, the use of MDA identification techniques was not sufficient to evaluate the presence of ROS in the media. Moreover, the reaction between MDA and proteins is very complex and is dependent on temperature, $\mathrm{pH}$ and the incubation period of samples (Shin et al., 1972). However, the ability of MDA to react with proteins in the media has not been identified in boar semen. Thus, the results of this study suggest that the toxic effects of polyvinylpyrrolidone may have more strongly influenced the semen quality.

Aside from the use of the Percoll technique, both chlorogenic acid and vitamin $E$ have shown positive effects on boar semen quality until 48h of storage. Both substances have been studied as protective agents of oxidative stress in semen, probably due to their inhibitory effects on ROS (Mendez et al., 2013; Pereira et al., 2014). Until 72h, only ChA has a positive effect. Pereira et al. (2018) have shown the benefits of ChA until 72h of storage of cooled boar semen, suggesting the potential use of ChA as a protective agent to a greater degree than vitamin $\mathrm{E}$, especially for storage times close to $72 \mathrm{~h}$ or more. In fact, numerically there were fewer abnormal cells in semen stored for $72 \mathrm{~h}$ when compared to semen without addition of 
antioxidants. The increase in the number of abnormal cells with vitamin $\mathrm{E}$ in semen stored for $72 \mathrm{~h}$ was also observed. Mendez et al. (2013) observed a linear increase in acrosoma damage by increasing the concentration of this vitamin from 100 to $400 \mu \mathrm{g} / \mathrm{mL}$. The authors attribute this result to the fact that high concentrations of this vitamin may have been oxidized in samples stored for a long time, which could have changed the characteristics of the plasma membrane, affecting its fluidity and, consequently, its cellular structure (Dalvit et al., 1998). In this case, studies should be conducted to prove any long-term toxic effects of this vitamin.

Vitamin E has already been widely studied because of its protective effects against oxidative damage in sperm (Jeong et al., 2009; Satorre et al., 2012). Similarly, chlorogenic acid has recently been proven to benefit cellular functionality and animal health (Darvesh et al., 2010; Sato et al., 2011) and also the quality of boar semen (Pereira et al., 2014), probably due to its antioxidant properties that reduce ROS. It is known that ROS are able to induce sperm capacitation by mechanisms not fully elucidated (O'Flaherty et al., 2006). In this sense, one of the events that occurs during sperm capacitation is the membrane cholesterol output (Signorelli et al., 2012). In the present study, it was found that the Percoll technique was not sufficient to induce sperm capacitation (Figure 2), except in fresh semen ( $0 \mathrm{~h}$ ) when chlorogenic acid was added to the extender. This result suggests that the presence of chlorogenic acid in semen coupled with the stress caused by the Percoll technique enables some mechanism involved in sperm cholesterol efflux.
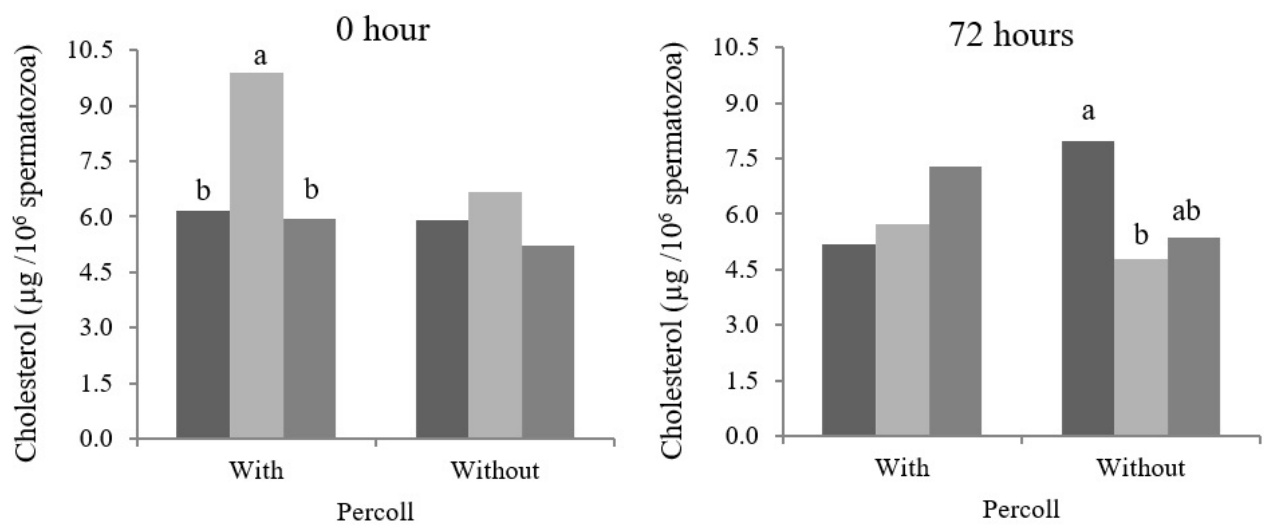

\section{Control $\square$ CA $\square$ VE}

Figure 2. Cholesterol concentration in seminal plasma of cooled boar semen after the addition of chlorogenic acid (CA) $(4.5 \mathrm{mg} / \mathrm{ml})$ or vitamin $E(V E)(400 \mu \mathrm{g} / \mathrm{ml})$ to the extender, with or without the use of the Percoll sperm selection technique. Means followed by different letters differ by Tukey's test $(P<0.05)$.

On the other hand, this effect of chlorogenic acid was not observed in semen stored for $72 \mathrm{~h}$. Otherwise, when compared to the control group (without addition of antioxidants), chlorogenic acid reduced the cholesterol efflux, but only in semen not processed in Percoll. The same was not observed with vitamin E. This result suggests a late antioxidant effect of chlorogenic acid when compared to vitamin E, mitigating the oxidative stress that occurs in semen stored for prolonged periods. In fact, chlorogenic acid resulted in increased motility only in the semen stored for $72 \mathrm{~h}$ and not processed in Percoll (Figure 1). This chlorogenic acid effect was also observed by Pereira et al. (2014). However, the benefits provided by chlorogenic acid to the cooled boar semen were not enough to prevent the loss of sperm quality after processing in Percoll.

In general, the results of the present study showed that the greatest benefit of the Percoll selection method was to reduce the percentage of abnormal sperm cells and that the addition of antioxidants to the semen extender can mitigate the harmful effects caused by the use of this technique. However, these benefits were not sufficient enough to prevent the loss of sperm quality after using Percoll. In this sense, further studies should be conducted in an attempt to improve the quality of boar semen processed in Percoll for later use in Al programs. 


\section{Conclusion}

The addition of chlorogenic acid to the semen extender improves the quality of boar semen processed or not in Percoll sperm selection technique, better than those obtained with vitamin E supplementation. However, the benefits are not enough to prevent the loss of sperm quality after using this technique.

\section{Acknowledgements}

The authors thank CAPES (PNPD Institutional), number process 2457/2011 and Pesquisador Visitante Especial - PVE, process number 88881.030399/2013-01), FAPEMIG (PPM-00359-14), CNPq (PQ 305478/2015-0), Minitub do Brazil and Fazenda São Paulo for their support.

\section{References}

Ahluwalia B, Holman R. Fatty acid composition of lipids of bull, boar, rabbit and human semen. J Reprod Fertil. 1969;18(3):431-7. http://dx.doi.org/10.1530/jrf.0.0180431. PMid:5788216.

Barak Y, Menezo Y, Veiga A, Elder K. A physiological replacement for polyvinylpyrrolidone (PVP) in assisted reproductive technology. Hum Fertil (Camb). 2001;4(2):99-103. http://dx.doi.org/10.1080/1464727012000199371. PMid:11591264.

Basile A, Ferrara L, Pezzo MD, Mele G, Sorbo S, Bassi P, Montesano D. Antibacterial and antioxidant activities of ethanol extract from Paullinia cupana Mart. J Ethnopharmacol. 2005;102(1):32-6. http://dx.doi.org/10.1016/j.jep.2005.05.038. PMid:16040216.

Blom E. A one-minute live-dead sperm stain by means of eosin-nigrosin. Fertil Steril. 1950;1(2):176-7. http://dx.doi.org/10.1016/S0015-0282(16)30125-X.

Breininger E, Beorlegui NB, O'Flaherty CM, Beconi MT. Alpha-tocopherol improves biochemical and dynamic parameters in cryopreserved boar semen. Theriogenology. 2005;63(8):2126-35. http://dx.doi.org/10.1016/j.theriogenology.2004.08.016. PMid:15826678.

Breininger E, Descalzo A, Rossetti L, Abramovich D, Beconi MT. Boar sperm functionality is related to atocopherol content after freezing-thawing. Andrologia. 2011;43(6):409-15. http://dx.doi.org/10.1111/j.1439-0272.2010.01094.x. PMid:21486419.

Brezezińska-Slebodzińska E, Slebodziński AB, Pietras B, Wieczorek G. Antioxidant effect of vitamin E and glutathione on lipid peroxidation in boar semen plasma. Biol Trace Elem Res. 1995;47(1-3):69-74. http://dx.doi.org/10.1007/BF02790102. PMid:7779577.

Cesari A, Kaiser GG, Mucci N, Mutto A, Vincenti A, Fornes MW, Alberio RH. Integrated morphophysiological assessment of two methods for sperm selection in bovine embryo production in vitro. Theriogenology. 2006;66(5):1185-93. http://dx.doi.org/10.1016/j.theriogenology.2006.03.029. PMid:16647751.

Chio KS, Tappel AL. Inactivation of ribonuclease and other enzymes by peroxidizing lipids and by malonaldehyde. Biochemistry. 1969;8(7):2827-32. http://dx.doi.org/10.1021/bi00835a020. PMid:5808335.

Dalvit GC, Cetica P, Beconi M. Effect of a-tocopherol and ascorbic acid on bovine in vitro fertilization. Theriogenology. 1998;49(3):619-27. http://dx.doi.org/10.1016/S0093-691X(98)00012-0. PMid:10732040.

Darvesh AS, Carroll RT, Bishayee A, Geldenhuys WJ, Van der Schyf CJ. Oxidative stress and Alzheimer's disease: dietary polyphenols as potential therapeutic agents. Expert Rev Neurother. 2010;10(5):72945. http://dx.doi.org/10.1586/ern.10.42. PMid:20420493.

De Lamirande E, Gagnon C. Reactive oxygen species and human spermatozoa. II. Depletion of adenosine triphosphate plays an important role in the inhibition of sperm motility. J Androl. 1992;13(5):379-86. PMid:1331007.

De Vos A, Nagy ZP, Van de Velde H, Joris H, Bocken G, Van Steirteghem A. Percoll gradient centrifugation can be omitted in sperm preparation for intracytoplasmic sperm injection. Hum Reprod. 1997;12(9):1980-4. http://dx.doi.org/10.1093/humrep/12.9.1980. PMid:9363717. 
Guimarães ACG, Leivas FG, Santos FW, Schwengber EB, Giotto AB, Machado CIU, Gonçalves CGM, Folchini NP, Brum DS. Reduction of centrifugation force in discontinuous percoll gradients increases in vitro fertilization rates without reducing bovine sperm recovery. Anim Reprod Sci. 2014;146(34):103-10. http://dx.doi.org/10.1016/j.anireprosci.2014.02.016. PMid:24646635.

Henkel RR, Schill WB. Sperm preparation for ART. Reprod Biol Endocrinol. 2003;1(1):108. http://dx.doi.org/10.1186/1477-7827-1-108. PMid:14617368.

Iwasaki A, Gagnon C. Formation of reactive oxygen species in spermatozoa of infertile patients. Fertil Steril. 1992;57(2):409-16. http://dx.doi.org/10.1016/S0015-0282(16)54855-9. PMid:1735495.

Jeong Y-J, Kim M-K, Song H-J, Kang E-J, Ock S-A, Mohana Kumar B, Balasubramanian S, Rho G-J. Effect of alpha-tocopherol supplementation during boar semen cryopreservation on sperm characteristics and expression of apoptosis related genes. Cryobiology. 2009;58(2):181-9. http://dx.doi.org/10.1016/j.cryobiol.2008.12.004. PMid:19141297.

Kato Y, Nagao Y. Effect of PVP on sperm capacitation status and embryonic development in cattle. Theriogenology. 2009;72(5):624-35. http://dx.doi.org/10.1016/j.theriogenology.2009.04.018. PMid:19604569.

Le Lannou D, Blanchard Y. Nuclear maturity and morphology of human spermatozoa selected by Percoll density gradient centrifugation or swim-up procedure. J Reprod Fertil. 1988;84(2):551-6. http://dx.doi.org/10.1530/jrf.0.0840551. PMid:3199373.

Lewis SEM, Aitken RJ. DNA damage to spermatozoa has impacts on fertilization and pregnancy. Cell Tissue Res. 2005;322(1):33-41. http://dx.doi.org/10.1007/s00441-005-1097-5. PMid:15912407.

Ma H, Liu D, Wang W, Wang L, Fu B, Li Z, He X. Effect of semen extender supplementation with trehalose, vitamin $C$ and $E$ on post-thaw min pig sperm qualities. Cryo Letters. 2015;36(5):308-12. PMid:26574677.

Maneesh $\mathrm{M}$, Jayalekshmi $\mathrm{H}$. Role of reactive oxygen species and antioxidants on pathophysiology of male reproduction. Indian J Clin Biochem. 2006;21(2):80-9. http://dx.doi.org/10.1007/BF02912918. PMid:23105620.

Martín-Hidalgo D, Barón FJ, Robina A, Bragado MJ, Llera AH, García-Marín LJ, Gil MC. Inter-and intrabreed comparative study of sperm motility and viability in Iberian and Duroc boar semen during long-term storage in MR-A and XCell extenders. Anim Reprod Sci. 2013;139(1-4):109-14. http://dx.doi.org/10.1016/j.anireprosci.2013.04.001. PMid:23660365.

Matás C, Vieira L, García-Vázquez FA, Avilés-López K, López-Úbeda R, Carvajal JA, Gadea J. Effects of centrifugation through three different discontinuous Percoll gradients on boar sperm function. Anim Reprod Sci. 2011;127(1-2):62-72. http://dx.doi.org/10.1016/j.anireprosci.2011.06.009. PMid:21784589.

Melo CL, Queiroz MG, Arruda Filho AC, Rodrigues AM, de Sousa DF, Almeida JG, Pessoa OD, Silveira ER, Menezes DB, Melo TS, Santos FA, Rao VS. Betulinic acid, a natural pentacyclic triterpenoid, prevents abdominal fat accumulation in mice fed a high-fat diet. J Agric Food Chem. 2009;57(19):8776-81. http://dx.doi.org/10.1021/jf900768w. PMid:19754196.

Mendez MF, Zangeronimo MG, Rocha LG, Faria BG, Pereira BA, Fernandes CD, Chaves BR, Murgas LD, Sousa RV. Effect of the addition of IGF-I and vitamin E to stored boar semen. Animal. 2013;7(5):793-8. http://dx.doi.org/10.1017/S1751731112002285. PMid:23211508.

O'Flaherty C, De Lamirande E, Gagnon C. Positive role of reactive oxygen species in mammalian sperm capacitation: triggering and modulation of phosphorylation events. Free Radic Biol Med. 2006;41(4):528-40. http://dx.doi.org/10.1016/j.freeradbiomed.2006.04.027. PMid:16863985.

Pereira BA, Chaves BR, Teles MC, Pontelo TP, Oliveira CR, Souza RV, Rodríguez-Gil JE, Zangeronimo MG. Chlorogenic acid improves the quality of boar semen subjected to cooled storage at $15^{\circ} \mathrm{C}$. Andrologia. 2018;50(5):e12978. http://dx.doi.org/10.1111/and.12978. PMid:29508428.

Pereira BA, Zangeronimo MG, Sousa RV, Teles MC, Mendez MFB, Rocha LGP. Effet de l'acide chlorogénique sur la peroxydation lipidique et la capacité antioxydante du sperme de verrat. Journées de la Recherhe Porcine. 2014;46:293-94.

Pope CE, Zhang YZ, Dresser BL. A simple staining method for evaluating acrosomal status of cat spermatozoa. J Zoo Wildl Med. 1991;22(1):87-95.

Pursel V, Johnson L, Rampacek G. Acrosome morphology of boar spermatozoa incubated before cold shock. J Anim Sci. 1972;34(2):278-83. http://dx.doi.org/10.2527/jas1972.342278x. PMid:4551736.

Sato Y, Itagaki S, Kurokawa T, Ogura J, Kobayashi M, Hirano T, Sugawara M, Iseki K. In vitro and in vivo antioxidant properties of chlorogenic acid and caffeic acid. Int J Pharm. 2011;403(1-2):136-8. http://dx.doi.org/10.1016/j.ijpharm.2010.09.035. PMid:20933071. 
Satorre MM, Breininger E, Beconi MT. Cryopreservation with alpha-tocopherol and Sephadex filtration improved the quality of boar sperm. Theriogenology. 2012;78(7):1548-56. http://dx.doi.org/10.1016/j.theriogenology.2012.06.023. PMid:22925635.

Shen T, Jiang ZL, Li CJ, Hu XC, Li QW. Effect of alpha-lipoic acid on boar spermatozoa quality during freezing-thawing. Zygote. 2016;24(2):259-65. http://dx.doi.org/10.1017/S0967199415000155. PMid:26099848.

Shin BC, Huggins JW, Carraway KL. Effects of $\mathrm{pH}$, concentration and aging on the malonaldehyde reaction with proteins. Lipids. 1972;7(4):229-33. http://dx.doi.org/10.1007/BF02533218. PMid:5040879.

Signorelli J, Diaz ES, Morales P. Kinases, phosphatases and proteases during sperm capacitation. Cell Tissue Res. 2012;349(3):765-82. http://dx.doi.org/10.1007/s00441-012-1370-3. PMid:22427115.

Zhou QZ, Feng CQ, Zou YG, Shu W, Li TQ, Li F, Liu CD, Mao XM. Single- and two-layer gradient centrifugation in sperm separation: comparison and appraisal. Zhonghua Nan Ke Xue. 2010;16(3):217-9. PMid:20369547.

\section{Author Contributions:}

SSR: Data curation, Project administration, Supervision, Methodology, Writing - original draft; COR: Data curation, Methodology; TPP: Data curation, Methodology; BRC: Data curation, Methodology; BAP: Data curation, Methodology; WES: Data curation, Methodology; JVP: Conceptualization, Supervision, Writing - review \& editing; LJP: Conceptualization, Supervision, Writing - review \& editing; MGZ: Conceptualization, Formal analysis, Funding acquisition, Investigation, Supervision, Writing - review \& editing. 